\title{
THE WAYS OF CHILDREN'S GAMES NOMINATION AND THEIR ETHNOLINGUISTIC RECONSTRUCTION
}

\section{Tyshchenko O. V.}

\section{INTRODUCTION}

Language is an exponent of culture and mentality, a powerful source of ethnical energy code. The ethno-linguistic picture of the world has its own special representation in each national language. Ethno-cultural doctrine of ways to verbally encoding of cultural information, stereotyping, and conceptualizing a reality, the relations between mental and linguistic units are covered in the studies by V. Von Humboldt, O. O. Potebnya, E. Sapir, B. Whorf, Y. D. Apresyan, D. S. Likhachev, Y. N. Karaulov, A. Vezhbitskaya and others ${ }^{1}$.

\section{Research subject and approaches}

Ethnolinguistic information covers the basic aspects of the world model (temporal, spatial, axiological, etc., but it is very selective (number of similar elements may have a cultural (linguistic) content the designation and the other is devoid of similar marking. In the functional aspect ethno-cultural information is diverse, and has different "versions": ordinary, mythological, religious, etc. that can exist in society parallelly and even coexist in the mind of one speaker ${ }^{2}$.

This approach became possible through the efforts of various anthropocentric scientific paradigms directions that proclaimed the thesis of language and culture isomorphism and the possibility of their investigation by typologically similar methods, including the linguistic facts reconstruction through the different phenomena of traditional folk culture and folklore conceptualization. Such phenomena include GAME, which belongs to interdisciplinary categories, contains "different types of interpersonal communication in all its forms and defines the role of game models in the different thinking types, behavior and human activity formation according to N. Arutyunova ${ }^{3}$.

\footnotetext{
${ }^{1}$ Шарманова Н. М. Етнолінгвістика. Навчальний посібник для студентів факультету української філології. Кривий Ріг. 2015. С. 7-8.

${ }^{2}$ Березович Е.Л. Язык и народная культура. Этнолингвистические исследования. Москва. 2007. С. 9.

${ }^{3}$ Арутюнова Н.Д. Виды игровых действий / Логический анализ языка. Концептуальные поля игр. M. 1997. C. 5.
} 
Firstly, N. D. Arutyunova distinguishes two types of human activities: 1) isolated games, separate from coriander (material) players' interests, for example, games for training, fun, excitiment, pastime and self-affirmation, as well as games, with and without toys, partner and addressee (viewer); 2) games "combined" with or "involved" in human behavior in society, games disguised, hidden. First type includes "invented", artificially created games such as chess and cards, shackles and hide and seek, doll games, ball, etc., everything they play, not what they do ${ }^{4}$.

According to I. A. Morozov, I. S. Sleptsova ${ }^{5}$ game communication forms two types of main game texts: descriptive, intended in order to move participants into a conditional game situation (such as viewing events or symbolic objects, which are found in the game "gate", "bridge", etc.) and signal, which inform about the beginning or end of stages of the game action.

Theoretical reflections and typologies are based on the original thesis: it is in terms of content, game elements mostly support "semantic" text and explain its context, and the game is of extremely symbolic formation. Emerging and developing in specific social, geographical, economic and cultural conditions, all folk games (along with typological features) have ethnic specificity, they are sublimated by mentality, philosophy and spiritual history of the people, the genesis and poetics, peculiarities of folk poetry and functioning in folk of life ${ }^{6}$. In various aspects, the game' semantics was considered by S. Tolstoy, V. Starko, O. Berezovich, M. Zhuykova. In this way, the subject of interest of M. V. Zhuykova is an analysis of the nominations and verbal accompaniment of the Eastern Slavic game, known in the Ukrainian tradition as the name of the горюдуб (in Russian горелки). In her turn T. Vendina's became interested in the semantics of playing in the offfield denotates, i.e. non-children's (not actually the discourse of the game, but rather near-game secondary verbal incarnations of the game concept itself) mobile games (elements, nature, erotica, animal, sexual behavior, wedding motives, holidays, playgrounds, pagan origins, entertainment, fun, pastime, (Russ. вечеринки, посиделки, беседы (parties, meetings, conversations), violation of ethics concerning extramarital relations, etc.) ${ }^{7}$.

\footnotetext{
${ }^{4}$ Арутюнова Н.Д. Виды игровых действий / Логический анализ языка. Концептуальные поля игр. M. 1997. C. 9.

${ }^{5}$ Морозов И.А., Слепцова И.С. Круг игры. Праздник и игра в жизни севернорусского крестьянина (X1X - XX вв.). Москва. 2004. С. 166.

${ }^{6}$ Гуменюк П.О. Парадигма гри в українському фольклорі (семантичний та функціональний аспекти). Автореф. дис... канд. філол.наук. Київ. 2008. С. 3.

${ }^{7}$ Вендина Т.И. Игра в языке русской традиционной культуры: этнокультурная интерпретация / Логический анализ языка. Концептуальные поля игр. ред. Н.Д. Арутюнова. М. 1997. С. 375.
} 
According to A. Berezovich and K. Pyankova, the game «models the living space in its various images - and it has reflected in the text (discourse) of the game, its verbal incarnation, the totality of everything that was spoken or told by the participants of the game. The discourse of the game contains a variety of language units, reaching into different codes, motivational spheres (animals, plants, household appliances, crafts and activities). Therefore, the study of the game language involves the analysis of all its components - verbal design (game discourse), physical actions (movement and postures of players, their location in space), "subjectescort " - all of which should be considered in close connection and interpenetration ${ }^{8}$.

It should be noted that simulation and motor (somatic) children's games (games with kids) of ancient Slavs are strikingly similar, however cultural counterparts in the translation of differences are manifested in the figurative symbolism, specifics of sound repetitions, proper names and verbal accompaniment. Cf. a famous children's game during which the child slams into palm, in the Ukrainian tradition (Toci, Tосі, свині в просі..., а теля (коза) в капусті, а Ім 'ярек на грушиі), instead in Polish children's folklore the following saying is presented: Tosi-tosi, Pojedziem do Zosi, Koci, koci w łapki / Pojedziem do babki ${ }^{9}$ or another variant: Kosi, kosi kosiany, Pojedziemy do mamy, A od mamy do taty Jest tam pisek kudlaty A od taty do dziadka Da nam grosz na jabłka... ${ }^{10}$

\section{The defined aim presupposes the solution of the following tasks. Formulation of the aim and objectives of the article}

The purpose of the article is to consider semantic-motivational peculiarities of children's moving games functioning, in particular, in the handcuffs and shelters in certain Slavic ethno-cultural zones (Russian, Ukrainian, Polish in a fragmentary comparison with the West Slavic languages) compared to English-language versions of such games in the aspect of primary and secondary nominations. In terms of primary (word-forming nomination) it is necessary to analyze dynamic games created by composite nomination and affixation are separate phraseologisms and persistent expressions that are associated with them. Let us pay attention to word-forming nests of games related to the hiding

\footnotetext{
${ }^{8}$ Березович Е.Л. Язык и народная культура. Этнолингвистические исследования. Москва. 2007. C. 342 .

${ }^{9}$ Gołęmbiowski Ł. Gry i zabawy różnych stanów w kraju całym lub niektórych tylko prowincjach. Warszawa. 1831. S. 5-6.

${ }^{10}$ Gołęmbiowski Ł. Gry i zabawy ludu / Zbiór wiadomości do antropologii krajowej. T. X. 1886. S.246.
} 
the participants or individual items, correlated with the ancient root archetypes *baba, *hovati, *žmuriti, *imati. Some titles for games with internal form need separate discussion that requires special semanticcultural reconstruction and explanation given to the role of verbal objects and realities formulas and sayings in different game components and situations, symbolic objects and their semantic dynamics (root*čur $b$ ). In terms of secondary nominations it should be noted that individual models of their semantic derivation - metaphorical and metonymic, related to numerical, somatic, spatial, plant and animal codes (games with secondary rite symbolism like ${ }^{*}$ choroniti), a link of games to ancient material culture, in particular hunting habits of wild animals reflected in other small folk forms, particularly in riddles. Particular emphasis is placed on ways of marking games in the dialects such as hide and seek in Russian dialect space.

\section{Outline of the main research material}

Due to referring to some English-speaking folklore sources we have an opportunity to highlight thematic groups of English traditional games as mobile, story, folk, role-playing, sports, imitation, group, relay games, fungames, and so on. The division of traditional English children's games is possible to depict as follows:

\section{- Tag Games}

Ball tag, Chain tag, Cops and robbers (Cowboys and Indians), Freeze tag, Ghost in the graveyard, Kiss chase, Stuck in the mud, Blind man's buff, British bulldogs (Sharks and minnows), Capture the flag (Stealing Sticks), Duck, duck, goose, Duck on a rock, Kabaddi, Kick the can, Marco Polo (game), Monkey on Woodchips (Grounders), Pie, Poison, Puss in the corner, Ringolevio, Statues (red light, green light; Grandmother's Footsteps), Tumbang preso, What's the time, Mr Wolf?

- Hiding Games

Hide-and-go-seek, Sardines

- Games with Equipment

Ball games, Ball in a Cup, Baseball, Basketball, Beanbag toss, Catch, Conkers, Continuous cricket, Dandy shandy, Dodgeball, Football, Four Square (Kingey), French cricket, Ga-ga, Hand Ball, Hoop rolling, Horseshoes. Kickball, Kick-to-kick, Knife game, Lagori, Marbles, Minkey, Mumblety-peg, paddle ball, Paper football, Queenie, Silent ball, Soccer Hockey, Spinning top, Spud, Stickball, String games, Stoop ball, Tennis, Tether Ball, Tug Of War 
- Jumping Games

Ampe, from Ghana, Double Dutch (jump rope), Hopscotch, Jumping Jacks, Jumping rope (Skipping rope), Jumpsies (also known as Chinese jump rope, elastics, or gummitwist), Leapfrog

- Memory Games

Chinese whispers, Here Comes an Old Soldier from Botany Bay (Old Soldier), I went camping and I..., Parlour Games, Hunt the Thimble (Hot and Cold), Huckle buckle beanstalk (Hot buttered beans), Truth or Dare?, Wink Murder

- Clapping games

Double Double This This, Down Down Baby, Down by the Banks

Hand games Mary Mack, Pat-a-cake, Rock-paper-scissors,Thumb war

Iconic function of the signs is reflected generally in the semantics titles of English mobile games. Game names include metaphorical reconsideration, including ethno-cultural realities and toponomastic code (Cats and mice, Hare and hounds, the British Bulldog).

Let's take a brief look at English games formed by word formation, or gaming composites based on the ethnographic source, mentioned above. Word formation, as a way of naming games, is high with the activity of one consecutive term. In the study area it was found 15 composites representing $15.8 \%$ of the total number of monosyllable nominations.

Game-Composites that are based on the productive "Simple Base + Simple Base" type are represented by a single model N + N: Bridgeboard. Names of this games model can be reduced to the following grammatical subtypes: noun + noun- All-hid, Cobblers-Hornpipe, Bun-hole, Cockfight, Bell-horses, Cock-fight, Bird-apprentice. verb + verb-Catch-pull; verb + noun- Bandy-ball, Bandy-wicket, Bend-leather, Spy- arm, Stoolball; adjactive + noun- Barley-break; noun + adjective-Bubble-justice; with a dash with a single partner: noun-and-noun- Pop-and-Bonnet.

In the course of the research, we've found out the names of the game with sentence structure wher specific realities of English cuisine function: Carry my lady that London; Mother, Mother, the Pot boi ls over; A ll the Soldiers and the Town; Here stands a Young Man; Little Dog, I call you; Mary mixed a Pudding up.

The composite nomination of children's games in the Slavic languages is mostly related to the somatic code, the names of the games are based on lexicalized verb-object phrases, and the name itself can only be similar in motivation ( with denotations quite different). For example, 
the Polish game drapinos looks like following: 'з покладених один на одного невеличких предметів треба пір 'ям, так, щоб не зрушити 3 місия інші предмети, дістати якийсь предмет; якщо хтось зрушить иі предмети або вини впадуть, то інший учасник гри по носі йом дряпає пір'ям¹. Some of the names are motivated by the bottom body names in conjunction with a specific action sign (accompanying actions - кланятися ' $\mathrm{w}$ której przodem i tyłem sobie się kłaniają') kłanidupka Wisła VIII, $715^{12}$. At the same time in some Russian, for example, in Olonitsky dialects (such an additional accompanying sign is the sign of beating) as in a game called гузнобитка to indicate another children's game. Rules and the course of this game is completely different from the Polish. The point of the game for adults is a гузнобитка that 'two men, or less often, girls run up to each other, banging their backs, and hit their seats; then run again, etc; the winner is considered to have driven his opponent to the other end of the room' (this play is described in detail in the Olonets dialect by G. Kulikovsky 1898) ${ }^{13}$.

Let us now consider the means of semantic derivation of games correlated with different cultural codes in Russian dialects. First, let's consider the metaphorical method of nomination in Russian dialect dictionaries and folklore descriptions for the most part of the first half of the XIX century. Separately, we analyze the semantic field of games related to the blinds and burial of participants or objects in terms of the explicit/implicit nomination of the respective game complexes, the associated verbal accompaniment and the terminology of actions, participants, subjects and game formulas.

As $\mathrm{T}$. Vendina rightly points out, in the Russian dialects the semantic range of the game is extremely wide. It clearly distinguishes several semantic registers - ontological, metaphorical and even communicative ${ }^{14}$. All of these codes are reflected in our traditional blindfolded games (concealers and hatchets) we consider, where one participant or several participants catch each other, having numerous formal and structuralsemantic variants, or, according to S. Neklyudov's terminology, allomotives.

Most clearly in the language of folk culture and in traditional mobile games, in particular, somatic-corporeal and spatial codes are presented,

\footnotetext{
${ }^{11}$ Słownik gwar polskich. Ułożył Jan Karłowicz. Kraków 1903. T. 1-6. T. I. S. 367.

12 Ibid. T. II. S. 374.

13 Словарь русских народных говоров, вып. 1-36. Москва-Ленинград (СПб.): Наука 1965-2002. Т. 7. С. 209.

${ }^{14}$ Вендина Т.И. Игра в языке русской традиционной культуры: этнокультурная интерпретация / Логический анализ языка. Концептуальные поля игр. ред. Н.Д. Арутюнова. М. 1997. С. 376.
} 
for example, in games such в ляпки ('перегонка', beat with a hand дать ляпок in the form of formal-structural variants лепки, ляпки, ляпочки, пятнашки ${ }^{15}$; the safe space in the game is encoded by the phrase быть на дереве - being on a tree - by the condition of the game the hunter has no right to catch a rabbit on a tree, which means simply to step on some pinch or rot in the game 'bunny') ${ }^{16}$. In Nizhny Novgorod province, finding a stick and sticking it in the ground, the blindfolder says: «Скрадена пошла/По домам пошла/Кого первого найдет, то за скраденой пойдет». "She went stolen / She went home / Whom she will find first, she will go after the stolen one. "Sometimes she shakes the stick and shouts, "Don't steal my wand !"17, thereby securing themselves from losing; in another game, one catches, and the tired one can чураться (flinch), that is, run to some place, for example, to a tree, grasping for it, say "Chur me"; then it cannot be caught ('Запуски' 'Launches') ${ }^{18}$. Similar motivations are also found in the Ukrainian traditional culture, which presents the ancient semantic archetypes of games related to the scapes: Цур дучки... на чотири пучки, на п'ятий мізинець - зацурують дучку, як гуляють хлопці у gлега, чи в масла, чи в свинки: одіходить чого чого од дучки $i$ заиурує; а не зачурає, той, що пасе, заме дучку, а ему все пасти, Цур палічча, Хто баби не веде, того трясия нападе Панас, Панас, кинься до нас! ${ }^{19}$.

Ukrainian folklorists see in the game of киць-баба the elements of the ancient maternity rite, believing it to be a fragment of a ritual dedicated to the Maternity cult. It was performed by women "on the floor" who were waiting for children, because the meaning of such a game was precisely to catch the children and determine the sex of the future child. In the Russian game, чур мой! there is a city-circle surrounded by pegs; participants run away, hide, after a while the people standing in the circle shout together: «Оврасоли, соли, был в городе, никого не боюсь!» Завидя одного из спрятавшихся. Кто-нибудь кричит: Чур мой! Чур мой и бежит в город... <..> Если отыскивающие уйдут далеко от города, спрятавшиеся выскакивают, бьют их шапками и занимают город. Незащитившие города должны снова отыскивать

15 Мудрость народная. Жизнь человека в русском фольклоре. Москва. Репринт 1991. Вып. 1. Младенчество Детство. С. 408.

${ }^{16}$ Ibid. C. 342.

${ }^{17}$ Ibid. C. 446.

${ }^{18}$ Ibid. C. 418.

${ }^{19}$ Українські приказки, прислів‘я і таке інше. Уклав М.Номис; упоряд., прим. М.М.Пазяка. Київ, 2004. C. 257. 
опрятавшихся ${ }^{20}$. Compare also a game situation in a game called чyp $c$ гвоздем! The game begins with a nail being driven into the ground by some gun. All players at the same time hit the nail one time, except for one - the "«вожельщик»", who at the end of the killing tries to remove the nail from the ground through those or other wooden devices ... Everyone is hiding. Then the вожельщик, taking the nail out of the ground, searches for the hidden ones, when he finds or sees someone, then tells him: чур с гвоздем!...

In connection with the symbol and nomination of the cultural archetype of $4 y p$, we will return to the nomination of some traditional children's Russian games, motivated by archaic roots - $y y p$ - within the certain word-forming nests. Cultural names with this inner form are presented in numerous dialect derivatives in the Russian language to indicate the course of the game, in game actions and different realities, which mainely contain elements related to the magical actions of delineating the circle around the players, defining a safe space for children's moving game, attributes or verbal accompaniment of games: in a word, protect yourself from something ',' make 'थyp' to protect yourself from mistakes, 'произнести «чур», чтоб оградить себя от ошибок, погрешностей', 'при игре сказать «чур!» в знак отказа участвовать в ней некоторое время' ${ }^{21}$. In non-game contexts, this verb still has the meaning of 'promise not to do anything' (Зачурались mеnерь старые: не сеют табак, Чулым., Новосиб.), ( $С$ тех пор зачурался на ведмедя ходить, Краснояр., Енисей), biceps of silence, 'to shun, to become a stranger '; зачуркаться 'to utter 'чyр', to secure oneself from unclean power, to whip, зачуркивание 'to pronounce the word 'чyp' with the outline of a circle in order to protect oneself from unclean sandly' (Novgorod), зачурник the one who has secured whom from unclean power (Pskov, Dahl), to bewitch 'enchant', a feast 'enchanted man or animal $^{22}$. D Some idiomatic compound words and sayings are associated with the idea of borders, boundaries, such as Через чур иконь не cтупит (*чур - межа), Чур одному -не давать никому ${ }^{23}$.

In the English folklore tradition the Ticky, ticky Touchwood game, my black chicken is known as a cultural-semiotic parallel ... She lays eggs for

\footnotetext{
${ }^{20}$ Мудрость народная. Жизнь человека в русском фольклоре. Москва: Репринт 1991. Вып. 1. Младенчество Детство. С. 444.

${ }^{21}$ Словарь русских народных говоров, вып. 1-36. Москва-Ленинград (СПб.): Наука 1965-2002. T. 8. C. 183.

${ }^{22}$ Ibid. C.418.

${ }^{23}$ В.М. Мокиенко, Т.Г. Никитина, Е. К. Николаева Большой словарь русских пословиц Москва: Астрель, 2010. С. 998.
} 
gentlemen ... The essence of this game is presented in Sheffield Glossary called "Tiggy Touchwood": One player named Tiggy tries to touch the tree, for example, the door ... Then he leaves his place, removes and passes through the playground, with all the players that must touch the leader and run to take his place earlier ... Tigie, chasing the players, forces them to touch the tree before he touches them ${ }^{24}$.

According to the folk description highlighted in the study "Wisdom of People. The life of a man in Russian folklore. Infancy Childhood" (Moscow 1991) the attention is payed to the elements of the interior space (line, circle, border, angle, House, etc.), regulating the rules of the game, play locus, sections of the safe one and dangerius, the role and function of the leader is associated with he metaphorical code in Russian children's games: the ворон уходит за угол на свое сало, a large quadrilateral or circle called сало, lard. One catches the players run over.... But as soon as the player will come to the line the other players shout «Я на сале», and here he is on the hot place - a trait beyond which a player can rest as much as he wants, but how as soon as he runs out, the leader's assistants catches him. In the game of blind man's (Novgorod) a blind man is led to corner, saying: "«Поди в кут, где бабы ткут»; the players try to reach their place - in the frog's house ..., Upon reaching, the player says «домa, в своем дому» (playing 'frogs'); the runner can scream «На дому», and the pursuer does not beat him, but runs after another; the counselor is assigned a house; each party of players holds for stick or he puts a pole, thereby denoting his home, free space between the houses - the field ... run across, teasing while the leader «Дедушка-рожок, на печи дыру прожег...one of the players can help out ...Run to the house of the leader and is touched by the hand to the caught (game'Дедушка-рожок'), the name of this game also comes from the corresponding formula, sentence; 'Терем' (Терем терем за всяким деревом - they catch each other, a place to play - a shallow pit or a gutter, choose someone in the pit to "grind" , others, running back and forth, say: Smolnik, smolnik, smolcho something they stole from you ... Smolnik Catching Runners » (Smolnik game ) - action code of the game (model 'acting character or participant - game' $)^{25}$.

${ }^{24}$ Dictionary of British folk-lore. The traditional games of England, Scotland, and Ireland with tunes, singing-rhymes, and methods of playing according to the variants extant and recorded in different parts of the kingdom/collected and annotated by Alice Bertha Gomme. Vol. 2. London: David Nutt. 1894. P. 292.

25 Мудрость народная. Жизнь человека в русском фольклоре. Москва: Репринт 1991. Вып. 1. Младенчество Детство. С. 444. 
It is a well-known fact, that in the language of folk culture and folklore the space of the house, as mastered and safe, is contrasted with the forest as dangerous, alien, undeveloped, as evidenced in part by the game in Kostroma, which in Ukrainian folklore corresponds to (in the "соответствует (в «похоронах Кострубоньки») the character Кострубонько. Ср. Костромушка в лес ушла, чужа дальня сторона, sretens for Kostroma participants: Смотри, ногу не сломи, Нас по миру не пусти, (Dialog - locuses) its death and recovering from death - в бане in late games: Костромушка умерла - Кострома оживает ${ }^{26}$.

The same game or similar games, motivated by, for example, numerical code, have different symbols and action and subject plans. So, the numerical symbolism (even/even, even/not even) is analogous to our game Орел и Решка. J.Karlovich classifies this game as a borrowing from the Belarusian language (Cot i liszka = Cetno i licho ust. Z Litwy 'grać $\mathrm{w}$ cotkę i liszkę, cotny = parzysty, Ciotka zgadnij, ciotka czy liszka') ${ }^{27}$. In NKPP proverbs also witnessed several variants of this statement 'Cetno czy licho , Komu lichem, komu padnie cetnem, Jutro pokaże cetno albo licho, Komu padnie cetno, komu licho, which are derived from the ancient game of "paired/unpaired, ${ }^{28}$.

In the English version, we find the name Odd or Even "odd or even", which was surrounded by magical actions of participants. This is a game of boys playing with buttons, marbles, and halfpence. The essence of this game is that one player hides several small objects in one hand, such as marbles, and asks his opponent to guess whether the number is odd or even. He then either pays or receives one of these items if he has guessed. The ethnographer Strutt notes that this game was known in ancient Greece and Rome ${ }^{29}$. This game in the English tradition is closely related to the magical symbolism of right and left as positive or negative. Gambling such as even-numbered, something or nothing, etc., before the player can make a choice, he spits on his own hand, and, pinning his middle finger with a pin, watches the direction in which the saliva flies to the right or left, and from here, by his own rule, determines what will be his guess ${ }^{30}$.

\footnotetext{
${ }^{26}$ Мудрость народная. Жизнь человека в русском фольклоре. Москва: Репринт 1991. Вып. 1. Младенчество Детство. С. 401.

${ }^{27}$ Słownik gwar polskich. Ułożył Jan Karłowicz. Kraków 1903. T. 1-6. T. I. S. 257.

${ }^{28}$ Nowa księga przysłów i wyrażeń przysłowiowych polskich. T. 1-4. Red. J. Krzyżanowski, S. Swirko. Warszawa: Państwowy Instytut Wydawniczy 1969-1978. T. I. S. 235.

${ }^{29}$ Dictionary of British folk-lore. The traditional games of England, Scotland, and Ireland with tunes, singing-rhymes, and methods of playing according to the variants extant and recorded in different parts of the kingdom/collected and annotated by Alice Bertha Gomme. Vol. 2. London: David Nutt. 1894. P. 147.

${ }^{30}$ Domestic folklore / by rev. T. F. Thiselton Dyer, M.A., Oxon., Cassell, Petter, Galpin \& Co., London - Paris - New York. T. 5. 1881. P. 100.
} 
Metaphorically substitutive nominations are found in many games related to plant and zoomorphic components (player actions mimic radish stretching or cow milking). Thus, in the Olonets tradition (the North Russian area) it is certified both as a name for the game and as a guess the name of the корову doumb. "Imitating the milking of cows, the girls pull and pick their hands with wet straw pressed down by a stone in a pan, and in the resulting sounds they try to catch vowels from the name of their fiancé" ${ }^{31}$, тянуть редьку 'old youth game'. One is grabbing the bracket, and everyone else is pulling each other until the first one comes off - everyone will fall, laugh, radish, редька, в хрен (the image of this game and the participants are those things бабушкаредька, корень-бабка, продавеи-покупатель) ${ }^{32}$. Here, firstly, the situation of exchange, (the conceptual sphere of exchange), purchase and sale (paintings, paints, etc.), the presence of two antagonists, warring parties (wolf - sheep), etc., the raven mistress ${ }^{33}$ is presented, sometimes mutual treats or gifts, a choice of two proposed alternatives. Secondly, in Russian outdoor games, where participants try to catch each other, the image of war and the metaphorization of hostilities, capture and imprisonment, game situations related to the free-connected opposition, the idea of Will, the symbol of release from captivity or imprisonment are relevant, (castle), crime and punishment, including physical (whipping). Compare motives and actions in the game 'shackles' (forge/unfasten, fre/tied, accompanied by a certain dialogue ${ }^{34}$. For example, the game shackles determined dialect polysemy certified in two ways (both movable and entertaining game and a calendar game, which takes place on public holidays); the first value is also due to the fact that the player "must jump a certain distance on one but on a straight line, if he gets off the line or touches the ground with his leg raised or bent, then he is beaten". In the second sense (the area of Muscovia) «В кандаль играли зимой и ребята и девки, один охраняет, один свободный, а остальные закованные, стоят, при иьому примовляють: я раскую одного", спрошу - А тебе кого? - Друга моего, - называет кого хочет, его то толкают и наоборот пихают друг к другу» ${ }^{35}$. As you can see, the relevant the rigid movements of participants in this

${ }^{31}$ Словарь русских народных говоров, вып. 1-36. Москва-Ленинград (СПб.): Наука 1965-2002. Вып. 14. С. 350.

32 Мудрость народная. Жизнь человека в русском фольклоре. Москва: Репринт 1991. Вып. 1. Младенчество Детство. С. 368-369.

${ }^{33}$ Ibid. C. 346.

${ }^{34}$ Ibid. C. 384.

35 Словарь русских народных говоров, вып. 1-36. Москва-Ленинград (СПб.): Наука 1965-2002. T. 13. C. 38 . 
case motivate the name of the game (the model 'character and course of the game and the role of participants - the game').

Thirdly, metaphorically marked funerary and wedding-erotic motifs are very often presented in calendar-rite games, in which wedding and funerals act as a secondary symbol with the corresponding function of objects used, for example, in divination. This is eloquently presented in the dialect names похороньл жировки ${ }^{36}$, золотце хоронить (Уж я золото хороню $л и)^{37}$. Thus, the word жировка only in one of its dialect meanings "Things in divination about the saints", mainely, "a quadrangular tablet on which a piece of bread, sand and a ring is laid". Her fortuneteller turns and purrs: Жировку хороню», «В ночь на Новый год похороны жировки. Берут решето: в него ложат уголь, хлеб, печень, серебро. Закрывают платком, поют: Уж я жировку хороню, Ко святому вечеру, Ко Васильевскому. Жировка миленька, окошки велики, косящатые, Kосящатые, решащетье» ${ }^{38}$. In the entertainment and fun of young people in Russian culture (on the gazebo, in the vicinity of the city of Vologda) under the name of ходить со вьюном guys and girls walk around the room, holding hands and changing places. This game is described as follows: " Parnas sit down against the girls, and the song is sung: „Уж я со вьюном хожу”. At this time, one of the girls walks around the hut with a handkerchief in her hand. When the song ends, she goes to one of the guys, kisses him and gives him a handkerchief, sitting in his place. Then the guy walks through the hut with a handkerchief to the same song, at the end of which he kisses one of the girls, etc. The game continues until all the shouting are kissed ${ }^{39}$.

To metaphorical simulation-games with zoomorphic component can still carry the game recorded in the Smolensk region called crane "A game that girls play during the arrival of cranes. "На святой неделе, во время прилета журавлей, девки играют в ,журавля". Берутся „гужем” за руки, становятся в одну линию" "40. This game is reminiscent of a famous game that is riddled with ancient cosmogonic motives associated with the appeal to the rain; (cf. the Ukrainian children's game "Don't Go, Don't Rain, I'll Boil You"), which is the English version of the game with the following saying: "Often in the summer, when thunderstorms and rain

${ }^{36}$ Словарь русских народных говоров, вып. 1-36. Москва-Ленинград (СПб.): Наука 1965-2002. T. 21. C. 145.

${ }^{37}$ Ibid. T. 11. C. 336.

${ }^{38}$ Ibid. T. 9. C. 185.

${ }^{39}$ Ibid. T. 6. C. 66.

${ }^{40}$ Ibid. T. 9. C. 229. 
interrupt some play outside, young voices can be heard shouting, "Не $\check{u} \partial u$, не йди дощику, зварю тобі борщику" 41 .

Imitation-metaphorical symbolic actions can be traced both in those game complexes where players catch each other, in moving games, and in those where participants perform a passive role, sit in place, repeating some actions and movements of the leader (many games related to traditional Slavic crafts). Let's consider them in detail on folklore, ethnographic and lexicographic material in a comparatively typological aspect.

Pay attention to the Slovak game called "Tkame platno, tkame"42, its course and participants are the same as in a similer Czech game Girls submitting each other hands, forming a long line (chain), simulating long piece of expanded canvas. The front of the players in the series by its leader makes various intertwined movements. The last two girls at the end raise their hands in the form of an arch. The front of the chain, led by its leading player, runs under the arch and, pausing, each pair is rotated under their own hands, thus the first pair becomes the last, and the last one becomes the first as if weaved and interwoven the canvas. By the way, this game in Russian culture is called "Ручеек" or "Воротия". In particular game "Воротиа" is as follows: participants stand in couples and, raising their hands, form a passage for other players to play/walk around through gates "Two of the players form two pillars. Then, lifting up one arm, they hold a scarf in them, replacing the crossbar on the gate. One pair after another runs through these gates, forming also a gates" ${ }^{\text {" }}$.

In Russian lingvokulture, particularly in the Permian dialects there are a lot of game pieces, associated with mixing clay for making pots (presented the names глину месить, горшечников сряжать), other household realities are (булавку прятать), for games some items are used for example, уламки горщиків (пор. коланец 'осколок глиняного горшка' игра в коланџы, коланцы по воде пускает (де коланцы "круглые камешки, косточки, округлье осколки глиняной посуды, употребляемые в играх $)^{44}$. Synonymous designations in Russian dialects (in this case we can speak of a kind of analogue dialect synonymic row) is represented in metaphorical phrase пускать блинки - stone and circles on the water, which differ from the abandoned stone in a game that is

\footnotetext{
${ }^{41}$ Domestic folklore / by rev. T.F.Thiselton Dyer, M.A., Oxon., Cassell, Petter, Galpin \& Co., London Paris - New York. T. 5. 1881. P. 24.

${ }^{42}$ Orlov St. Hry a pisnę̌ dẹ̆ti slavanskỳh. Praha: Nakladem československè obce sokolskè 1928. S. 199.

43 Словарь русских народных говоров, вып. 1-36. Москва-Ленинград (СПб.): Наука 1965-2002. T. 5. C. 124

${ }^{44}$ Ibid. T. 14. C. 11.
} 
similar to the game of в коланциь ${ }^{45}$. In Polish ethnic culture them in a similar zoomorphic metaphor expressed by an idiomatic compound Kaczki kidać "to put stones on the water surface" (to throw duks).

Let us briefly dwell on the nomination, symbolism, and verbal accompaniment of games in the twists and turns in various local traditions of the Slavs in order to identify the typology of images and motives. However, we do not aim to describe the entire nominal repertoire of these games and their genesis. We emphasize only that in ancient archetypes *chovati, *žmuriti, *slepъ, *baba, *pogrebati, *choroniti, *kryti and so on. Researchers (V.M.Toporov, M.V.Zhuikova, S.M.Tolstaya, etc.) reconstruct the metaphorical code of death, blindness and funeral rite, cf. Slavs. žmur "deceased" and its characteristic attribute of blindness and blindness and their designation, ukr. хованки, стукалки-хованки, схованки, Polish chowanki, Russ. poc. жмурки, ухоронки, схоронки, жмуркышки, жмуркушки, Polish ślepy byk, ślepa babka, ciemna babka, zmrużek, baba w miech, 'ciciubabka', babiludek, Ukr. кiui, куu̧a, uฺiųiбаба, Панас, Афанас. (Хто баби не веде, того трясия нападе, Панас, Панас, кинься до нас!). Even Ukrainian ethnographer V. Hnatyuk claimed that there were such links between the boyko, Carpathian games $\theta$ лопатки, грушки (в забавах «при меричи») with ancient mythological code and otherworld.

The most common aspect in these games is the verbal one. Thus, if a blind woman is located far enough from the players, they cried (Sama voda, sama voda!), And if she is closer, the children shout "Hori, Horí! Hori okno!"46 (in this case known to many games symbolic opposition hot/cold also is realized). It should be noted, that the idea of burning and, in general, the temperature sign of the nomination is represented in the playing field of many situations, including those related to the burial of participants or objects (the reconstruction makes it possible to attribute to this semantic series some other associative-symbolic parallels, such as горю дуба, Rus.горелки and кругле пекло. For example, actsional code in which one of the players is blindfolded and searches for other players or objects certified (in the vicinity of Poznan) as a word-combination kokota bić, gdy się z parobek zawiazanymi oczyma zbliza sie do garnka, wszyscy wotaja: "Ciepło !" - When the blindfolded man approaches the pot, everyone shouts "Heat" 47 . Note the Polish phrase goracy kamień, in this case, obviously, we are talking

\footnotetext{
${ }^{45}$ Ibid. T. 3. C. 25.

${ }^{46}$ Orlov St. Hry a pisnẹ̆ dẹ̆ti slavanskỳh. Praha: Nakladem československè obce sokolskè. 1928. S. 295.

${ }^{47}$ Słownik gwar polskich. Ułożył Jan Karłowicz. Kraków 1903. T. 1-6. T. II. S. 207.
} 
about one of the joint team games, which got its name from the verbal formula, a spell that says one of the participants: "Stoje, stoje na goracym kamieniu, Kto mnie kocha, ten mnie zmieni"48.

It also should be noted that the symbolic archetype *baba mentioned in the gambling games has been repeatedly mentioned in other games and cultural traditions not related to the hide and sick. Comp. the Russian game, attested even in the dictionary of V. Daly баба-горлянка ${ }^{49}$, тесная баба ('Игра школьников. Сидя на лавке, тесно прижавшись друг к другу, дети двигаются к середине, в конце концов вытесняя кого$н и б у д b{ }^{50}$ with the same meaning and motivational signs in the Ukrainian language the game is represented under the name of кісна/тісна баба"an old folk game in which those sitting at the ends of the bench press on those sitting in the middle, trying to displace and take their place" 51 . Ukrainian game name a woman to carry complements synonymous repertoire of games involving throwing stones on the water, which we discussed above, Колика-баба "A child's game, consisting in the fact that the player jumps on one leg along the intended line, trying not to stray from it”, attested in the Vladimir region in and certified dictionaries, including "Dictionary of the Russian Academy" in $1911^{52}$.

Numerous inter-regional synonymous names also have an English game associated with the ritual-burial code. Here are some of them: "Belly Mantie", "Billy Blind", "Blind Bucky Davy", "Blind Harry", "Blind" ${ }^{53}$. By evidence of ethnographers, these and similar to them games are a remnant of the ancient rites of sacrifice and changing closes, here, obviously, they are largely motivated with zoomorphic code, and the person caught, was dressed in the skin of a bear or a wolf.

In Malopolska and southern Ukraine, the game of the жмурки contains a common animal code that goes back to the origin of animal hunting practices. So, in the Polish bobr game, players choose one by the beaver, the other by the hunter, the rest by the greyhounds. Hunters show the greyhounds the place where the beaver was hidden, but beforehand the Greyhounds sang: "A mój mily bobrze, schowajże się dobrze, od nedzieli

\footnotetext{
${ }^{48}$ Ibid. T. I. S. 105.

49 Словарь русских народных говоров, вып. 1-36. Москва-Ленинград (СПб.): Наука 1965-2002. T. 3. C. 25.

${ }^{50}$ Ibid. T. 2. C. 1.

51 Жайворонок В. Знаки української етнокультури. Словник-довідник. Київ: Довіра 2006. С. 21.

52 Словарь русских народных говоров, вып. 1-36. Москва-Ленинград (СПб.): Наука 1965-2002. T. 14. C. 134.

${ }^{53}$ Dictionary of British folk-lore. The traditional games of England, Scotland, and Ireland with tunes, singing-rhymes, and methods of playing according to the variants extant and recorded in different parts of the kingdom/collected and annotated by Alice Bertha Gomme. Vol. 2. London: David Nutt. 1894. P. 40.
} 
do nedzieli, by cię charci newidzieli" ${ }^{54}$. In Kherson region (its different is that in this case, one player is hiding here, and everyone else is looking for him), while singing: «Бобре, бобре, ховайся добре! Я хорти маю, в поле пускаю, дзвони задзвонять - хорти зайця догонять, як спіймають, икіру здеруть, - на кілочки повісять». Somewhere the one hiding was beaten, apparently, imitating the killing of prey ${ }^{55}$.

Similar motivations are found in some English-language games called Catch the Badger or Kill the Bear. English ethnographers Emsley and Jason record this game in the London area. Synonymous with this game in Marlborough, according to Patterson is "Tom Tuff". - Strong Tom. The author gives other variants and descriptions of the games ${ }^{56}$ Badger the Bear. The children hold in their hands the ropes of wild animals 'beasts, which they beat, the Bear, tied to the rop. They start to beat him only on a certain signal.

We emphasize, that scenario of hunting prey and hunt is reflected in Some English alphabet riddles about insects and parasites. Compare this riddle text, in which as household predety (gun), and most about' objects (prey) are represented: My prey I seek the fields and weeds about, / and have more teeth then [than] beasts within the land, / and whensoever my game I have found out, / then safe I bring it to my master's hand. / Upon my back the deere he laves and there doth kill one. sometimes more: / he shuts me up and goes his wayes, better contented then [than] before.-It is a combe, and a louse killed upon the backe of it. < Animals Hunted $>^{57}$.

Very similar ideas underlie the mysteries of spines and parasites. They do not, however, regard lice as a game, but as things to be kept or thrown away ${ }^{58}$. Similar motifs are presented in the Frisian mystery, where motives for hunting prey with a flock of dogs are presented: The hunting scene varies greatly in details and occasionally admits cloments belonging to other riddles. The horn plate and the notion of catching and throwing away game in the Frisian "A hunter went hunting with ton swift dogs. Each had a horn plate in front so that it could not bark. All that the hunter caught, he killed, and what he did not catch, he carried

\footnotetext{
${ }^{54}$ Orlov St. Hry a pisnę̆ dẹ̆ti slavanskỳh. Praha: Nakladem československè obce sokolskè. 1928. S. 303.

55 Покровский Е.А. Детские игры: преимущественно русские. Санкт-Петербург.1994. Репринт. Москва. 1985. С. 115.

${ }^{56}$ Dictionary of British folk-lore. The traditional games of England, Scotland, and Ireland with tunes, singing-rhymes, and methods of playing according to the variants extant and recorded in different parts of the kingdom/collected and annotated by Alice Bertha Gomme. Vol.2. London: David Nutt. 1894. P. $227-228$.

${ }^{57}$ Taylor A. English Riddles from Oral Tradition Berkeley and Los Angeles. 1951. P. 158.

${ }^{58}$ Ibid. P. 159.
} 
with him ${ }^{59}$. Hounds and hunters are presented as the main semiotic codifier in English bowling puzzles where animals function, represented hunting, catching, running, along with their respective names - body parts of animals: Sixe haires did come within a plain, / whom hounds had started out the nest. / Hill up, hill downe they runne amaine, / till they were weary and then the rest. / They caught him once, and scapt again, / more eager went they than before, / and tooke more paine then (as I win) / to beare away the game and more. / The hounds and hunters all were one, / each liked his game and tooke his prey. / But when their sport was past and done, / they left their haires and came away. - 'Tis a match at bowles played in a bowling ${ }^{60}$.

\section{CONCLUSIONS}

Thus, different repertoire of mobile games of Slavs is compared to other related and distantly related cultures are repeatedly semiotic determined by a specific course of action game, its verbal and substantive support in various variants and typology allomotyves, national and cultural originality realities, specific formal verbalization nominate it. Game nominations are characterized, first of all, by the synonymy of semantic and word-forming variants, taken together in different Slavic zones, by a pronounced top onomastic and nickname code, word-forming nests of derivatives of games, belonging to one thematic group, associative and symbolic series of names, correlated with the idea of hot and burning, with deep mythological origins and represented in different importance of games and rituals, largely word formation derivatives of *baba, *imati and so on. Various metaphorical codes of games that represent metaphorical models of nomination in the correlation and close combination of action, subject and agency plans in some places reflect the connection with ancient customs and traditions in the material culture of a certain people (cf. hunting scenarios and hunting animals). The declared material can be developed in the analysis of the folklore discourse of games in different languages (cf. magic formulas-repetitions, nicknames, locuses of safe and dangerous space in the game, concepts of redemption, freedom, punishment, symbolism of refusal, etc.), prejudices and beliefs in various modern sports games featured in (Pickering D. Dictionary of superstitions, Cassel, 1995), in particular, the symbolism of right-left. Further

\footnotetext{
${ }^{59}$ Ibid. P. 360/

${ }^{60}$ Taylor A. English Riddles from Oral Tradition Berkeley and Los Angeles. 1951. H. 166-167.
} 
explorations in this regard may be other types of games, for example, cards that are riddled with numerous mythological and symbolic connotations, prescriptions, prohibitions and recommendations. So, it is considered to be an unfortunate sign when you are touched by a squinted person (see "EYE OF EVIL"), also the player should never sit cross-legged, because in this case he "exhausts" his luck. The cross and dogs are undesirable on the card table and the table itself should not be bare (ideally it should be covered with a happy green cloth), the motive of the bare (poor) - covered - uncovered $^{61}$. These ideas are reflected in the following passages referred to the dictionary: "It is unlucky to be touched by a crosseyed person (see EVIL EYE) during a game, and a player should never sit with his legs crossed in case he 'crosses out' his luck though some believe the opposite: see CROSS, DOGS are unwelcome at the card table and the table itself must not be bare (ideally it should be covered with luckgiving green cloth). Chips should always be kept in a neat pile on the table and never left in an untidy heap. It is thought best to choose a seat that allows the player to lay his or her cards down 'with' rather than 'against' the grain of the wood on the table ${ }^{62}$.

\section{SUMMARY}

Game contains different types of interpersonal communication in all its forms, defines the role of game models in forming different types of cognition, stereotypes of human behavior and activity, it is characterized by holistic, actional, spatial, object-functional, chronotropic, time coordinates, reflects elements of individual and collective experience of a certain society. Games concentrate mentality, philosophy and spiritual history of the nation, represent genesis and poetics, rituals and mythology, symbolism of objective, actional, agent and verbal code, specificity of objects and attributes functioning in folk mode of life (N. Arutiunova, O. Berezovich, T. Vendina, P. Humeniuk, M. Zhuikova, I. Morozov, I. Slieptsova, V. Starko and others).

The material of the research was based on the ethnographic and folk researches of the first part of $19^{\text {th }}$ - beginning of $20^{\text {th }}$ centuries, dictionaries of comparisons, proverbs and sayings, dictionaries of dialects, historical-etymological dictionaries of Polish, Ukrainian and

\footnotetext{
${ }^{61}$ Pickering D. Dictionary of Superstitions. Cassel, Wellington House. London. 1995. P. 56.

${ }^{62}$ Ibid. P. 56.
} 
Russian, etc. as well as other Slavonic languages in their comparison with English.

The object of the presented research is traditional children games in their contrastive and ethno-linguistic dimension; a special attention was paid to "blind man's buff" games in comparative-historical aspect. Their reconstruction on the basis of ethno-linguistic and linguo-conceptual methodology was suggested.

The research focuses on the repertoire of the defined games in different language and mythological pictures of the world, their etymology, semantic-motivational features considering their transparent or opaque inner form, reveals their word-formative peculiarities.

It provides metaphoric models (connected to numeric, objective, vegetative, animalistic and locative codes, the connection of games with the artifacts of material culture). It provides the description of individual structurally-semantic models of nomination, clarifies the peculiarities of magic-ritual formula functioning, facetious sayings regulated by the laws of the game, their symbolism and content (the archetypes of the Circle, Proto-Slavic roots *baba, *imati, *chovati, etc., the concept of Home, native and strange space, symbolism of the boundaries/border, semantic oppositions of different types free/bound, even/odd, toponomastic code, the connection with the cult of the Clan/Bloodline, burial rituals, etc).

A special attention was paid to the specificity of forming interdialectal synonymic lines of game nominations, to some semantic mechanisms of game senses transformations in nursery rhymes, riddles, phraseological units, idioms, to the nationally-cultural specificity of realia and attributes of the games, etc.

\section{REFERENCES}

1. Арутюнова Н.Д. Виды игровых действий / Н.Д.Арутюнова // Логический анализ языка. Концептуальные поля игр. Москва: Индрик, 1997. - С. 5-16.

2. Березович Е.Л. Язык и народная культура: Этнолингвистические исследования / Е.Л.Березович. - М.: Индрик, 2007. - 600 с.

3. Вендина Т.И. Игра в языке русской традиционной культуры: этнокультурная интерпретация / Т.И.Вендина // Логический анализ языка. Концептуальные поля игр., ред. Н.Д. Арутюнова. Москва: Индрик, 1997. - С.375-391. 
4.Гуменюк П.О. Парадигма гри в українському фольклорі (семантичний та функціональний аспекти). Автореф. дис. ... канд. філол.наук. Київ. 2008. - 18 с.

5. Жайворонок В. Знаки української етнокультури. Словникдовідник. Київ: Довіра 2006. - 703 с.

6. Мокиенко В., Никитина Т., Николаева Е.К. Большой словарь русских пословиц. - Москва: Олма Медиа Групп 2010. - 1024 с.

7. Морозов И.А., Слепцова И.С. Круг игры. Праздник и игра в жизни севернорусского крестьянина (X1X - XX вв.) / И.А. Морозов, И.С. Слепцова. - М.: Индрик, 2004. - 920 с.

8. Мудрость народная. Жизнь человека в русском фольклоре. М.,1991. Вып. 1 Младенчество; Детство.

9. Номис М. Українські приказки, прислів'я і таке інше. - Київ: Либідь, 2004. 768 с.

10. Покровский Е.А. Детские игры: преимущественно русские. СПб., 1994 (репринт - М., 1985)

11. Словарь русских народных говоров. Вып. 1-36. МоскваЛенинград (СПб.). 1965-2002.

12. Шарманова Н.M. Етнолінгвістика: навчальний посібник для студентів факультету української філології / Н.М. Шарманова; за ред. Ж.В. Колоїз. Кривий Ріг: НПП АСТЕРІКС, 2015. - 192 с.

13. A Dictionary of British folk-lore. The traditional games of England, Scotland, and Ireland with tunes, singing-rhymes, and methods of playing according to the variants extant and recorded in different parts of the kingdom/collected and annotated by Alice Bertha Gomme. Vol. 1. London: David Nutt 1894.

14. Domestic folklore / by rev. T. F. Thiselton Dyer, M.A., Oxon., Cassell, Petter, Galpin \& Co., London-Paris-New York. T. 5. 1881. - $212 \mathrm{p}$.

15. Gołęmbiowski Ł. Gry i zabawy różnych stanów w kraju całym lub niektórych tylko prowincjach / L. Gołęmbiowski. Warszawa: Druk N. Glucksberga, 1831. - 336 s.

16. Gołęmbiowski Ł. Gry i zabawy ludu polskiego / Zbiór wiadomości do antropologii krajowej, wydawany staraniem Komisji Antropologicznej Akademii Umiejętności”. Kraków. T. X. 1886. S. 246-336.

17. Nowa księga przysłów i wyrażeń przysłowiowych polskich. T. 1-4. Red. J. Krzyżanowski, S. Swirko. Warszawa 1969-1978. (NKPP) 
18. Orlov St. Hry a pisnȩ̌ dẹ̆ti slovanskỳh / St. Orlov. Praha: Nakladem československè obce sokolskè, 1928. - $986 \mathrm{~s}$.

19. Pickering D. Dictionary of Superstitions. Cassel, Wellington House, London: Cassell, 1995. - 294 p.

20. Słownik gwar polskich, ułożył Jan Karłowicz. - Kraków, 1903. T. 1-6.

21. Taylor A. English Riddles from Oral Tradition / A. Taylor. Berkeley and Los Angeles, 1951. - 959 p.

\section{Information about the author:} Tyshchenko O. V., Doctor of Philology, Professor at the Department of Foreign Languages and Translation Studies Lviv State University of Life Safety 35, Kleparivska str., Lviv, Ukraine Professor at the Department of Russian Studies University of Ss. Cyril and Methodius in Trnava 2, nam. Herdu, Trnava, Slovak Republic 